\title{
O RECRUTAMENTO MILITAR NA AMÉRICA PORTUGUESA: O ESFORÇO CONJUNTO PARA A DEFESA DA COLÔNIA DO SACRAMENTO (1735-1737)
}

\author{
Paulo César Possamai \\ Professor Adjunto da UFRN \\ Doutor em História Social pela USP
}

\section{Resumo}

Foi no esforço para defender a Colônia do Sacramento, sitiada pelos espanhóis de outubro de 1735 a setembro de 1737, que a Coroa portuguesa ordenou a mobilização de todos os recursos disponíveis no Estado do Brasil, humanos e materiais. O propósito deste artigo é fazer um estudo de como foi feito o recrutamento compulsório durante essa ocasião e saber como eram as condições de vida desses homens, tirados à força dos locais onde viviam para serem enviados à região platina, de onde poucos conseguiram voltar.

\section{Pallavras-Chave}

Guerra $\bullet$ Recrutamento $\bullet$ Soldados $\bullet$ Cerco $\bullet$ Vida Cotidiana

\section{Abstract}

In their effort to defend the Colônia de Sacramento, besieged by the Spanish from October 1735 to September 1737, the Portuguese Crown ordered the mobilization of all human and material resources available in the State of Brazil. This article examines the compulsory recruitment that occurred on this occasion and discusses the living conditions of those men who were taken by force from their homes to be sent to the River Platte area, from where few would return.

\section{Keywords}

War $・$ Recruiting $\bullet$ Soldiers $\bullet$ Siege $・$ Daily Life 
Com este artigo procuramos contribuir com as pesquisas efetuadas sobre o recrutamento militar e as condições de vida dos soldados na América Portuguesa. Caio Prado Júnior, em Formação do Brasil Contemporâneo, abordou o sistema de recrutamento quando fez sua análise da administração colonial. Enrique Peregalli, em sua obra, Recrutamento Militar no Brasil Colonial, concentrou seu estudo na capitania de São Paulo na segunda metade do século XVIII, quando ela se tornou o principal centro de recrutamento de soldados que lutaram contra os espanhóis nas guerras do sul. Nosso trabalho tem como objetivo contribuir com a pesquisa atualmente levada a cabo em Portugal por Fernando Dores Costa sobre o recrutamento militar no século XVIII. Concentraremos nosso foco de interesse num restrito recorte geográfico e cronológico: a Colônia do Sacramento durante o reinado de D. João V (1706-1750).

A Colônia do Sacramento foi fundada na margem esquerda do Rio da Prata em 1680 por D. Manuel Lobo ${ }^{1}$, obedecendo ao plano do príncipe regente D. Pedro de expandir os domínios portugueses na América, a fim de assegurar vantagens territoriais e econômicas à Coroa portuguesa. A ocasião era propícia, pois a decadente Espanha de Carlos II, o último Habsburgo espanhol, não parecia capaz de opor resistência aos velhos projetos expansionistas portugueses que visavam dominar o estuário platino e, através dele, assegurar a manutenção do fluxo da prata contrabandeada das minas de Potosí para Lisboa por via dos portos brasileiros.

Se a metrópole espanhola estava enfraquecida, a isolada fortaleza de D. Manuel Lobo não pôde resistir ao ataque combinado das forças coloniais espanholas e dos exércitos indígenas das missões jesuíticas, grupos para os quais a presença portuguesa no Rio da Prata constituía uma grande ameaça. A destruição de Colônia, levada a cabo oito meses após sua fundação, irritou profundamente o príncipe regente de Portugal que, sob ameaça de guerra, forçou a Coroa espanhola a restituir-lhe a posse do território de Sacramento, através do Tratado Provisional de 1681.

\footnotetext{
${ }^{1}$ No documento pelo qual o príncipe regente designou o mestre de campo D. Manuel Lobo para o governo do Rio de Janeiro, com a missão de fundar uma colônia no Rio da Prata, consta que ele tinha uma extensa folha de serviços no exército, no qual se engajara em 1652: fora soldado, capitão de infantaria, capitão de cavalaria ligeira e de couraceiros, comissário geral de cavalaria e mestre de campo, sempre agindo com destaque nas guerras da Restauração. Cf. "Carta patente... 08/10/1678” in: (Azarola Gil 1931: 162).
} 
Foram bastante difíceis os primeiros anos que se seguiram ao restabelecimento dos portugueses em Colônia, em 1682, quando as restrições do governo de Buenos Aires, que procuravam impedir o contrabando e a exploração do gado selvagem que abundava nos campos da margem norte do Rio da Prata, se somaram à corrupção generalizada que marcou o governo de Cristóvão Ornelas de Abreu (1683-1690). A situação melhorou sensivelmente sob as administrações de Francisco Naper de Lencastre (1690-1699) e de seu sucessor, Sebastião da Veiga Cabral (1699-1705), com o incremento da política de povoamento e a intensa exploração das riquezas pecuárias do atual território uruguaio. Porém, a Guerra da Sucessão Espanhola (1701-1714) colocaria Portugal e Espanha em campos opostos na Europa, resultando no desencadeamento das hostilidades no Rio da Prata.

De fato, a guerra entre as Coroas ibéricas logo chegou aos seus domínios americanos e, na madrugada de 18 de outubro de 1704, as tropas espanholas acamparam à vista das muralhas de Colônia. $\mathrm{O}$ exército invasor, comandado pelo sargento-mor D. Baltasar de García Ros, contava com duzentos cavaleiros e duzentos e oitenta infantes, aos quais acrescentavam-se quatro mil índios vindos das missões jesuíticas. Apesar da esmagadora desproporção entre o número dos atacantes e o dos defensores, que não passavam de setecentos soldados, o governador Sebastião da Veiga Cabral soube organizar a resistência e recusou todas as propostas de rendição feitas por García Ros. As tentativas de assalto foram frustradas com fortes perdas, o que levou os espanhóis a esperar que a fome obrigasse a rendição dos portugueses, já que uma pequena frota impedia o abastecimento de Colônia² .

Em 9 de janeiro de 1705, o governador de Buenos Aires, D. Alonso Juan de Valdés y Inclán (1702-1708), dirigiu-se ao acampamento espanhol com mais 200 soldados. Apesar da demonstração de força, as propostas de rendição feitas pelo governador Valdés y Inclán foram recusadas por Veiga Cabral, que já estava informado que se preparava no Rio de Janeiro uma pequena frota para buscar a guarnição e os moradores de Colônia (Almeida 1973: 285-286). A decisão do abandono da praça ligava-se à precária situação do Rio de Janeiro,

\footnotetext{
${ }^{2}$ Sobre a os acontecimentos referentes à tomada de Colônia em 1705, consultar: "Relación del sitio, toma y desalojo de la Colonia..." Lima, 1705, in: Revista del Instituto Histórico y Geográfico del Uuruguay, tomo VI, n 1, pp. 197-206.
} 
onde se temia um ataque francês e sofria-se com atividade dos piratas que assolavam a costa. Por sua vez, os problemas internos eram ainda mais graves, pois o êxodo para as minas privara a cidade dos homens e mantimentos necessários para o envio de uma expedição de socorro (Bicalho 1997: 214-2145).

A guerra terminou com a assinatura dos tratados de Utrecht (1713-1715), nos quais Filipe $\mathrm{V}$ teve de fazer várias concessões a fim de obter o reconhecimento das nações européias à ascensão dos Bourbons ao trono espanhol. O tratado de paz com Portugal, assinado em 1715, assegurou aos portugueses a devolução do território da Colônia do Sacramento. Os primeiros tempos da restauração de Colônia foram difíceis, devido aos problemas de abastecimento que marcaram o governo de Manuel Gomes Barbosa (1716-1722), mas a situação mudou radicalmente com a chegada do seu sucessor. A junção do apoio decidido da Coroa à grande capacidade administrativa do governador Antônio Pedro de Vasconcelos (1722-1749) foram os fatores responsáveis por um período de grande desenvolvimento que pode ser considerado como o apogeu da presença portuguesa no Rio da Prata.

Se, a princípio, todos os homens solteiros, entre os 17 e 30 anos, estavam aptos a serem inscritos nas tropas regulares portuguesas, uma série de privilégios concedidos pela Coroa a determinadas profissões e devoções religiosas oferecia refúgio a muita gente contra a atuação dos recrutadores (Costa 1998: 972). A disseminação dos privilégios que, muitas vezes se estendiam aos subordinados dos detentores dos mesmos (Costa 1995: 130), permitiu a criação de amplas redes de proteção contra o recrutamento compulsório (Costa 1996: 15), fazendo com que o alvo principal dos recrutadores recaísse sobre os vagabundos, malfeitores, trabalhadores itinerantes e todos aqueles que não contavam com a proteção das comunidades locais (Costa 1995: 126). Via de regra, esta era uma situação bastante comum na Europa durante o Antigo Regime, quando as monarquias buscavam evitar o recrutamento dos privilegiados e das camadas produtivas da sociedade.

Como exemplo podemos citar o que ocorreu na Bahia em 1762, quando o governo interino informou a Coroa sobre as dificuldades que encontrava para completar o Terço de auxiliares, "sendo a causa desta grande falta o grande número de privilegiados que tem esta terra". Entre os privilegiados listavamse os pedidores da S. S. Trindade, Santo Antônio e Meninos Órfãos, Tesoureiros da Bula da Santa Cruzada, familiares do Santo Ofício, moedeiros, relojoeiros, tanoeiros, carvoeiros, marinheiros, carpinteiros e calafates. Quanto aos "homens de negócio e seus caixeiros só querem alistar-se nas ordenanças, querendo entrar no número dos privilegiados, o que tudo faz um grande número de 
homens com que não só se podia completar o Terço de Auxiliares, mas ainda fazer outro" ${ }^{3}$ Não é de se estranhar que se buscasse antes a incorporação aos corpos de ordenança que às tropas auxiliares, uma vez que as ordenanças não só asseguravam um certo status social, como também garantiam a seus membros que não seriam enviados em missões para fora da área de atuação do regimento.

No Rio de Janeiro, também era grande o número de pessoas isentas do serviço militar, englobando os que serviam ou serviram nos cargos eleitos da governança, os senhores de engenho e seus criados, os moedeiros, os familiares do Santo Ofício e os Cavaleiros das Ordens Militares. Por sua vez, os desprivilegiados não hesitavam em fugir para o mato cada vez que se ameaçava com o recrutamento compulsório, não restando ao governador outra alternativa senão ordenar o alistamento dos vadios. Além da dificuldade em conseguir novos soldados, as autoridades cariocas tinham de combater contínua deserção dos soldados que, desde inícios do século XVIII, fugiam para o sertão, atraídos pelas riquezas de Minas Gerais (Bicalho 1997: 210 a 233).

Normalmente, o alistamento dos oficiais destinados à guarnição de Sacramento fazia-se no Reino, enquanto os soldados poderiam também vir da metrópole ou do Rio de Janeiro, a cujo governo Colônia estava subordinada. Já em 1679, ao organizar a expedição que viria a fundar a Colônia do Sacramento, D. Manuel Lobo ordenou o recrutamento compulsório de quantos homens pôde capturar no Rio de Janeiro: operários, aprendizes, comerciantes, mendigos e mesmo os presos, aos quais foi concedido o perdão em troca do alistamento (Monteiro 1937, v.1: 42). A câmara da cidade não deixou de protestar ao rei contra o procedimento do governador, pois, a fim de evitar o serviço militar, muitos agricultores e operários fugiram para as matas, abandonando os engenhos; prejudicando desse modo a economia local (Coaracy 1944: 191).

Se houve violência no recrutamento, o príncipe regente tentou garantir a boa vontade dos recrutas, ordenando a D. Manuel Lobo que pagasse um mês de soldo adiantado aos oficiais e soldados, enquanto os efetivos da cavalaria deveriam receber dois meses adiantados (Monteiro 1937, v. 2: 7). Contudo, o fundador não demorou a se queixar da "incapacidade da gente que trouxe do Rio de Janeiro”, soldados que, até então, “considerava maus só no militar os ex-

\footnotetext{
${ }^{3}$ Ofício do governo interino para Francisco Xavier de Mendonça Furtado. Salvador, 22/ 07/1762, in: Anais da Biblioteca Nacional do Rio de Janeiro, vol. 31, p. 503.
} 
perimentei malíssimos em todas as suas ações"; o que não surpreende se nos lembrarmos da forma como foi feito o recrutamento. Reclamou ainda que, aproveitando-se da enfermidade que padeciam, "os brasileiros se licenciaram tanto que desobedeciam a seus oficiais". Segundo Lobo, os melhores soldados eram os reinóis, já que, com poucas exceções, os brasileiros "iam muito pouco às faxinas e nelas trabalhavam o que queriam, que era muito pouco, e com aquela calma que no Brasil costumam fazer todas as coisas" (Lobo in Monteiro 1937, v. 2: 33).

As queixas contra os soldados brasileiros são constantes na documentação pesquisada. Em 1718, o governador Manuel Gomes Barbosa reclamava ao vice-rei do Brasil que muitos dos seus soldados eram aleijados e doentes (Barbosa in Monteiro 1937, v 2: 67). Escreveu também à Coroa sobre a grande quantidade de desertores que resultava da má qualidade da tropa, composta por soldados novos e mulatos, sendo em sua maioria "degredados, uns por ladrões e outros por vários crimes". Por isso achava melhor que se fizesse o recrutamento em Portugal e nas ilhas. Mas ainda achou necessário acrescentar que os recrutas não deveriam desembarcar no Rio de Janeiro "por não tomarem a língua da terra, que só desta sorte me parece não desertarão, por não saberem o viver do Brasil" 4 .

Segundo a opinião do governador Antônio Pedro de Vasconcelos, "o Brasil não tem gente para o recrutar, e a experiência mostra não serem os filhos daquele país mui próprios para a guerra". O Conselho Ultramarino não deixou de dar razão ao governador, dizendo que nos brasileiros "se acha mais frouxidão e [são] menos sofredores do trabalho" ". Em favor dos militares do Reino, contava o fato de que geralmente já tinham experiência militar antes de chegar aos domínios ultramarinos. José de Mirales, escrevendo sobre o ataque espanhol de 1735, escrevia que, face à cavalaria inimiga, composta por mil e duzentos soldados, os portugueses só contavam com cento e sessenta soldados, "porém quase todos estes, transmontanos, da Beira, de Entre Douro e Minho, já disciplinados, e bem instruídos na guerra passada, e tropas das ditas províncias de donde tinham vindo no ano de 1717 povoar a Colônia" (Mirales 1900: 95).

\footnotetext{
${ }^{4}$ Carta de Gomes Barbosa ao rei. Colônia, 15/12/1718. Arquivo Histórico Ultramarino, Colônia do Sacramento, cx. 1, doc. 40.

${ }^{5}$ Consulta do Conselho Ultramarino. Lisboa, 14/04/1722. Instituto Histórico e Geográfico Brasileiro, Arq. 1.1.21, ff. 78-81v.
} 
A falta de apreço pelos soldados brasileiros ia mais além do que o simples preconceito dos oficiais e governadores, reinóis em sua maioria. O recrutamento compulsório que visava à obtenção da maior quantidade de homens possível no menor tempo, e que também tinha por objetivo livrar as cidades dos elementos indesejados, foi o principal elemento responsável pela baixa qualidade do soldado recrutado na América portuguesa. Outro fator que pesava contra o soldado brasileiro era a falta de experiência no cavalgar, arte de extrema importância no pampa.

De fato, o que vemos é que o recrutamento compulsório de gente indesejável era o principal responsável pela baixa qualidade dos recrutas e não a sua terra de origem. Em 1732, o governador do Rio de Janeiro, Luís Vaía Monteiro (1725-1732), queixou-se de que Antônio Pedro Vasconcelos lhe remetera o soldado Diogo de Faria, considerado pelo governador de Sacramento como de ânimo "ferino e matador". Em resposta aos protestos enviados por Vasconcelos ao Conselho Ultramarino, Vahia Monteiro comprometeu-se a não mais enviar para Colônia "nem fracos, porque não servem para o serviço, nem os de gênio matador, ainda que esse seja o ofício dos soldados".

Laura de Mello e Souza ressalta que, devido às questões de fronteira, o sul da América portuguesa foi, durante o século XVIII, o principal destino reservado aos desclassificados da sociedade colonial. "Prender para Montevidéu', para a 'Nova Colônia', para o rio da Prata ou genericamente para o Sul são expressões correntes na documentação por todo o período" (Souza 1990: 83). À repressão que se seguiu aos levantes ocorridos durante o governo do conde de Assumar em Minas Gerais, seguiu-se a prisão dos "cabeças do motim, e muitos ociosos e vagabundos para Montevidéu” (Souza 1990: 111) As medidas repressivas, que visavam à restauração da ordem na capitania também serviram ao propósito de recrutar soldados para a expedição que então se organizava com o objetivo de fortificar o sítio de Montevidéu.

Com a finalidade de tornar a carreira militar mais atrativa, em 1731 a Coroa limitou o serviço no Brasil em dez anos e em Angola em seis anos, ao fim dos quais os militares poderiam pedir transferência para Portugal, caso não houvessem contraído matrimônio nesse meio tempo. Os incentivos, porém, não con-

\footnotetext{
${ }^{6}$ Carta de Vahia Monteiro a Vasconcelos. Rio, 29/08/1732. Arquivo Nacional, cód. 83, vol. 4, f. $104 \mathrm{v}$.
} 
seguiram aumentar consideravelmente o número de recrutas para as colônias (Boxer 1969: 163-164). O que garantia um certo número de militares era o costume de seguir a profissão paterna. De fato, o oficial Manuel Ferreira de Sande, fez um requerimento ao rei pedindo-lhe que dispensasse seu filho da idade mínima prescrita pelo regimento para o recrutamento, pois ainda lhe faltavam três anos. Alegava que era um costume do rei dispensar os filhos dos oficiais em tais circunstâncias ${ }^{7}$.

Ainda assim, o alistamento compulsório dos degredados do Reino e dos desclassificados da colônia era absolutamente necessário para a manutenção do efetivo das tropas coloniais, já que os constantes atrasos dos soldos e a violência do cotidiano militar eram motivos suficientes para afastar os voluntários. Por sua vez, os privilégios concedidos pela Coroa às ordens religiosas e a determinadas profissões, nos quais se incluía a isenção do serviço militar, tornou extremamente penosa a função do recrutamento.

No Rio de Janeiro, principal centro de recrutamento para a Colônia do Sacramento na América portuguesa, também era grande o número de pessoas isentas do serviço militar, englobando os que serviam ou serviram nos cargos eleitos da governança, os senhores de engenho e seus criados, os moedeiros, os familiares do Santo Ofício e os Cavaleiros das Ordens Militares. Por sua vez, os desprivilegiados não hesitavam em fugir cada vez que se ameaçava com o recrutamento compulsório, não restando ao governador outra alternativa senão ordenar o alistamento dos vadios. Além da dificuldade em conseguir novos soldados, as autoridades cariocas tinham de combater contínua deserção dos soldados que, desde inícios do século XVIII, fugiam para o sertão, atraídos pelas riquezas de Minas Gerais (Bicalho 1997: 210-233).

Tudo indica que a qualidade dos soldados remetidos para Colônia variou muito de acordo com a política adotada pelos governadores do Rio, já que os que não queriam desfalcar a guarnição da cidade remetiam os homens que não fariam falta, enquanto os que eram mais cuidadosos em garantir a segurança do estabelecimento platino tratavam de enviar a Colônia alguns dos melhores soldados da guarnição carioca. O governador Antônio Pais de Sande queixou-se, em 1693, de que a guarnição do Rio “estava reduzida a três compa-

\footnotetext{
${ }^{7}$ Requerimento de Manuel Ferreira de Sande. Arquivo Histórico Ultramarino, Colônia do Sacramento, cx. 3, doc. 260.
} 
nhias de soldados bisonhos, visto que os melhores elementos da tropa eram seguidamente retirados e enviados para a Colônia do Sacramento, a fim de preencher os claros que as contínuas deserções causavam na respectiva guarnição" (Coaracy 1944: 215).

Para fazer frente à constante falta de soldados, os governadores do Rio de Janeiro usavam todos os meios possíveis para prover ao recrutamento. As constantes chegadas de gente atraída pelas minas logo chamaram a atenção das autoridades para o seu enquadramento no sistema militar. A lei de 20 de março de 1720 impedia o embarque para o Brasil de pessoas sem passaportes. Contudo, ela não conseguiu cumprir seu intento de restringir a emigração dos portugueses, já que havia um grande desleixo na fiscalização dos navios, especialmente no Porto, principal ponto de embarque da região mais povoada do Reino (RussellWood 1998: 164). Se muitos homens optavam pela emigração como uma forma de escapar ao recrutamento militar na metrópole, nos portos brasileiros, especialmente no Rio, os recrutadores estavam a sua espera.

Antes mesmo de assumir o governo da Colônia do Sacramento, quando se encontrava no Rio de Janeiro à espera da saída de uma embarcação que o levasse ao Rio da Prata, Antônio Pedro de Vasconcelos entrou em acordo com o governador Aires de Saldanha (1719-1725) sobre a melhor maneira de aproveitar o grande o número de pessoas que continuamente chegavam àquele porto em busca de novas oportunidades no Brasil. Ao partir para Sacramento, Vasconcelos levou consigo trinta ilhéus que haviam chegado ao Rio sem passaporte e foram constrangidos pelo governador a segui-lo. ${ }^{8}$

Parece que a idéia de Antônio Pedro de Vasconcelos tornou-se prática comum a partir de então. Embora a lei obrigasse a remeter a Lisboa as pessoas presas por falta de passaportes, Luís Vahia Monteiro (1725-1732), sucessor de Aires de Saldanha no Governo do Rio de Janeiro, alegou que a contínua deserção em Colônia quase extinguiu a guarnição carioca, por isso, movido pela urgência, transgredia a lei para melhor servir à Coroa. Ordenou então, em fevereiro de 1729, que os homens recentemente chegados do Porto sem passaportes fossem alistados e remetidos para a Colônia do Sacramento 9 .

\footnotetext{
${ }^{8}$ Carta de Vasconcelos ao rei. Colônia, 25/09/1722. Arquivo Histórico Ultramarino, Colônia do Sacramento, cx. 1, doc. 76.

${ }^{9}$ Portaria do governador Luís Vahia Monteiro. Rio, 02/02/1729. Arquivo Nacional, cód. 60, vol. 17, f. 17v. Seriam mais de setenta os homens alistados nessa ocasião. Cf. Carta de Vahia Monteiro para Vasconcelos. Rio, 04/021729. Arquivo Nacional, cód. 87, vol. 3, f. 182.
} 
Em maio de 1735, o brigadeiro José da Silva Pais, governador interino do Rio, informava à Coroa sobre a chegada de duas embarcações vindas das ilhas Terceira e Faial, nos Açores, cuja "maior parte da sua carga é de passageiros, gente pedinte e que querem passar às minas não só a buscar vida senão ainda só a pedir esmolas"10. Como a maior parte dos que chegavam não possuía passaporte, Silva Pais tratou de impedir a passagem para Minas Gerais dos que não tinham sido chamados pelos pais ou parentes ou que tivessem uma forte razão para prosseguir a viagem. Os homens capazes para o serviço foram enviados para Colônia, para onde o governador já havia mandado vinte e sete no decurso de dois meses. Contudo, quando se tratou de enviar um casal com dois filhos, Silva Pais teve de enfrentar o provedor da Fazenda Real, que não concordou em pagar suas passagens, como convinha aos que partiam como povoadores.

Além de passageiros sem passaportes, o recrutamento compulsório atingia os homens que de alguma forma perturbavam a ordem pública. Em março de 1726, Vahia Monteiro enviou a Sacramento, como recruta, André de Siqueira, acusado de "inquietar uma mulher casada", o qual substituiria um soldado que deveria ser remetido ao Rio "para a consolação de seu pai" 11 . Tal procedimento tinha como objetivo evitar que a guarnição de Colônia tivesse seu efetivo reduzido cada vez que os familiares pediam a volta de um soldado ao Rio, como voltou a ocorrer em 1728, quando Vahia Monteiro mandou um recruta para que, em seu lugar, a pedido de seu avô, retornasse à guarnição carioca o soldado José Nunes. Curiosamente, fora o próprio avô de José Nunes quem pedira ao governador para enviá-lo a Sacramento alguns anos antes, e depois, já velho, pedia pela sua volta ${ }^{12}$.

Um momento privilegiado para a análise do recrutamento militar na América portuguesa, durante a primeira metade do século XVIII, ocorreu durante o esforço feito para tentar romper o cerco imposto pelos espanhóis à Colônia do Sacramento. Um incidente diplomático entre as cortes de Lisboa e Madri forneceu aos

\footnotetext{
${ }^{10}$ Carta de José da Silva Pais ao rei. Rio, 12/05/1735, in: Revista do Instituto Histórico do Rio Grande do Sul. Porto Alegre, I a IV trimestres de 1948, $\mathrm{n}^{\text {os }} 109$ a 112, pp. 84-85.

${ }^{11}$ Carta de Vahia Monteiro para Vasconcelos. Rio, 08/03/1726. Arquivo Nacional, cód. 87, vol. 3 , f. $27 \mathrm{v}$.

${ }^{12}$ Carta de Vahia Monteiro para Vasconcelos. Rio, 16/04/1728. Arquivo Nacional, cód. 87, vol. 3, ff. 135-135v.
} 
espanhóis um motivo para tentar desalojar os portugueses do Rio da Prata, dando início ao cerco de Colônia, que se estendeu de outubro de 1735 a setembro de 1737.

Num domingo de carnaval, dia 20 de fevereiro de 1735, os criados do embaixador português na corte espanhola, Pedro Álvares Cabral, Senhor de Belmonte, libertaram um homem que estava sendo conduzido preso pelos soldados pelas ruas de Madri, dando-lhe acolhida na casa do embaixador. Dois dias após, cem soldados invadiram o palácio do Senhor de Belmonte, prendendo todas as pessoas que lá encontraram. Embora Pedro Álvares Cabral protestasse contra a violência, de nada adiantou sua intervenção. A chegada da notícia desse incidente a Lisboa provocou a divisão dos conselheiros de D. João $\mathrm{V}$ entre os que propunham uma conciliação e os que exigiam uma represália imediata. O segundo grupo venceu e, a 13 de março, sessenta soldados e três oficiais ocuparam todas as entradas da casa do embaixador espanhol, Marquês de Capecelatro, prendendo doze criados seus que foram levados à cadeia do Limoeiro (Cortesão 1950: 59-63).

$\mathrm{O}$ incidente diplomático, que quase originou um conflito bélico entre as Coroas ibéricas na Europa e foi responsável pela irrupção da guerra na região platina, foi na verdade o estopim da tensão nos relacionamentos luso-espanhóis que vinham estremecendo desde 1733. O casamento dos príncipes herdeiros de Portugal e Espanha com as infantas espanhola e portuguesa, ajustado em 1725, mas realizado quatro anos após na fronteira luso-espanhola, fora pactuado num momento de irritação contra a corte francesa, que desfizera os ajustes para o casamento do delfim da França com a infanta de Espanha e não correspondia a um desejo sincero de maior aproximação com Portugal, de quem Filipe V guardava ressentimentos desde os episódios da Guerra da Sucessão Espanhola.

Por outro lado, o príncipe das Astúrias era alvo constante das intrigas de Isabel Farnésio, sua madrasta. Enquanto Isabel era a principal interessada em impedir que Filipe V cumprisse sua intenção de abdicar, D. João V manifestava a esperança de que a ascensão de seu genro ao trono espanhol aumentaria sua influência na corte de Madri. Provavelmente a intimidade que o embaixador português mantinha com os príncipes e seu envolvimento entre os partidários da abdicação de Filipe $\mathrm{V}$ foram os fatores responsáveis pela antipatia que Isabel Farnésio e seu valido, o primeiro ministro D. José Patiño, lhe devotavam. Além das intrigas da corte, a situação internacional também contribuiu para o fim da harmonia que existiu entre 1725 e 1733 entre as duas Coroas ibéricas. Em 1733, D. José Patiño negociou uma aliança franco-espanhola que ia contra os interesses portugueses, pois, por meio desse pacto, a 
França comprometia-se a ajudar a Espanha a conquistar os reinos de Nápoles e Sicília (que pertenciam à Áustria, aliada de Portugal) para o príncipe Carlos, filho de Filipe V e Isabel Farnésio (Cortesão 1950: 63-66).

A reviravolta da política de alianças, elaborada pela diplomacia espanhola, agradou sobremaneira os tradicionais inimigos dos habitantes de Colônia, os jesuítas e o cabildo de Buenos Aires, o qual, em 15 de abril de 1733 escreveu ao rei queixando-se dos excessos cometidos portugueses de Colônia na exploração do gado selvagem ${ }^{13}$. Patiño aproveitou o momento e, com a dupla finalidade de agradar os portenhos e hostilizar os portugueses, inteirou o novo governador do Rio da Prata, D. Miguel de Salcedo, das queixas do cabildo de Buenos Aires, ordenando-lhe que durante seu governo se informasse dos novos caminhos abertos pelos portugueses para o Brasil e destruísse todos os estabelecimentos, quintas, estâncias e animais que os portugueses possuíssem fora da área coberta pela artilharia de Sacramento, solicitando a ajuda dos índios missioneiros se fosse necessário. Devia ainda impedir todo o comércio entre portugueses e espanhóis e limitar aos lusitanos a navegação do Rio da Prata às rotas estritamente necessárias para a ligação de Colônia aos demais domínios portugueses (Cortesão 1954: 244-252).

Assim que chegou a Buenos Aires, em março de 1734, Salcedo empenhouse em cumprir as ordens recebidas. Na repressão ao contrabando, ordenou a substituição dos antigos fiscais reais, sendo que alguns deles foram presos e tiveram seus bens confiscados (Lisanti 1973, v. 4: 376-377). Também iniciou os preparativos militares na cidade, ordenando ainda a vinda de um contingente indígena das missões jesuíticas. Para manter em segredo os objetivos da mobilização, Salcedo anunciou que as tropas missioneiras se destinavam a pacificar o Paraguai, onde recentemente havia sido esmagada a revolta dos comuneros ${ }^{14}$.

Ainda em março do mesmo ano, Salcedo escreveu ao governador Antônio Pedro de Vasconcelos, informando-lhe que tinha ordem expressa de Filipe V para demarcar os limites da Colônia do Sacramento. Por sua vez, Vasconcelos respondeu-lhe que se achava sem instruções de D. João V para concordar em

\footnotetext{
${ }^{13}$ Acordo do Cabildo de Buenos Aires, 27/03/1734, in: Campaña del Brasil: Antecedentes Coloniales. Buenos Aires: Archivo General de la Nación, 1931, tomo I (1535-1749), p. 501.

14 “Rellaçam do principio da Guerra da Collonia..." in: Revista do Instituto Histórico e Geográfico do Rio Grande do Sul. Porto Alegre, III trimestre de 1945, nº 99, p. 42.
} 
delimitar o território de Colônia. Salcedo insistiu no assunto em outras duas cartas, enquanto que Vasconcelos continuava a alegar a sua falta de competência para tratar do assunto (Sylva 1993: 28-31). Entretanto, em 18 de abril de 1735, D. José Patiño comunicou ao governador Salcedo que o rei ordenou-lhe que tomasse Sacramento, sem esperar por uma declaração formal de guerra ${ }^{15}$.

Enquanto isso, na Europa, os governos de Lisboa e Madri iniciavam os preparativos para o conflito armado. Em cumprimento aos tratados de aliança com Portugal, em junho, entrou no Tejo uma esquadra inglesa composta de trinta navios e mais de doze mil homens. Ao mesmo tempo, a Coroa ordenou ao governador Vasconcelos que se prevenisse contra qualquer ataque espanhol, aviso desnecessário, já que o mesmo sabia do que se passava em Buenos Aires através das informações fornecidas pelos espanhóis que visitavam Colônia e pelos espiões que mantinha naquela cidade (Cortesão 1950: 68-69).

Embora não houvesse ordenado a evacuação da campanha com antecedência (o que seria ceder às pressões espanholas de não sair do espaço coberto pela artilharia), assim que recebeu o aviso de Lisboa, Vasconcelos iniciou os preparativos para a defesa. Para garantir a segurança da população que vivia fora do recinto fortificado, o governador enviou ao arraial de Veras, a cinco quilômetros do povoado, cento e vinte cavaleiros comandados pelos capitães Manuel Félix Correa e Inácio Pereira da Silva, com o objetivo de defender a campanha e se opor a qualquer movimento dos espanhóis ${ }^{16}$. A presença da tropa foi bastante útil aos moradores da região, que aproveitaram segurança proporcionada pela presença da cavalaria para retirar das quintas parte dos frutos e o gado doméstico, a fim de preparar-se para o sítio eminente (Sá 1993: 73).

Em 18 de outubro, as tropas espanholas avançaram até o rio de São José, a cinco léguas de Colônia, arrasando em seu caminho as estâncias portuguesas, onde prenderam os que não puderam fugir, apoderando-se de seus escravos. Vasconcelos ordenou então que os militares que vigiavam a campanha se recolhessem à povoação, onde continuava o trabalho de restauração das muralhas (Sylva 1993: 42-43). A aproximação do inimigo aumentou a pressa da po-

\footnotetext{
${ }^{15}$ Carta de D. José Patiño para D. Miguel de Salcedo. Aranjuez, 18/04/1735, in: Campaña del Brasil: Antecedentes Coloniales. Buenos Aires, Archivo General de la Nación, tomo I (1535-1749), p. 505.

16 "Noticia Práctica del sitio de la Nueva Colonia del Sacramento..." in: Revista Histórica. Montevidéu: Museo Historico Nacional, 1916, nº 22, tomo VII, p. 606.
} 
pulação rural em refugiar-se no recinto fortificado, levando consigo na fuga tudo o que podia ser transportado das quintas que eram cultivadas nos arredores da fortaleza (Sá 1993: 74). Na praça de guerra, os trabalhos de fortificação continuaram sem parar nos domingos ou dias santos, com a participação de toda a população, inclusive dos meninos da escola, que executavam o serviço cantando, como uma forma de suavizar o árduo trabalho ${ }^{17}$.

Na manhã do dia 20, as forças espanholas, compostas de mil e trezentos cavaleiros, já estavam à vista dos muros de Colônia. Tentaram levantar acampamento no alto de Santo Antônio, na quinta dos franciscanos, mas o fogo da artilharia portuguesa obrigou-as a retirar-se para trás de uma elevação natural, onde ficaram fora do alcance dos canhões da praça ${ }^{18}$. A surpresa que causou a Salcedo a firme resistência que encontrou quando esperava tomar de assalto uma povoação que seus informantes garantiam sem fortificação defensável, levou à mudança dos planos iniciais e à preparação de um sítio prolongado. Para isso, ordenou que trouxessem de Buenos Aires a artilharia necessária para bombardear a praça (Sá 1993: 76).

Apesar dos espanhóis também terem submetido Colônia a um bloqueio fluvial, uma embarcação sob o comando de Guilherme Kelly conseguiu sair furtivamente do porto de Sacramento, dirigindo-se para o Rio de Janeiro, para avisar o governador daquela capitania sobre o ataque espanhol. Em resposta aos pedidos de socorro de Antônio Pedro de Vasconcelos, o governador interino do Rio, José da Silva Pais, mandou lançar um bando para recrutar toda pessoa que quisesse participar do socorro à praça sitiada. A fim de conseguir a rápida adesão de voluntários, oferecia o fornecimento imediato de fardas, mantimentos e três meses de soldo adiantado a título de ajuda de custo. Findo o cerco, o voluntário poderia dar baixa após entregar o fardamento e as armas, sendo que, se quisesse continuar no serviço, teria a permissão de escolher a companhia de seu agrado nas guarnições de Sacramento ou do Rio de Janeiro. Oferecia ainda passagem e sustento aos casais que manifestassem o desejo de seguir para Colônia ${ }^{19}$.

Todavia, os incentivos oferecidos pelo governador sofreram a oposição do procurador da Coroa e do provedor da Fazenda Real, que alegaram não

17 "Noticia Práctica del sitio de la Nueva Colonia del Sacramento..." Op. cit., pp. 606-607.

18 "Rellaçam do principio da Guerra da Collonia..." Op. cit., pp. 42-43.

${ }^{19}$ Bando do governador Silva Pais. Rio, 19/11/1735. Arquivo Nacional, cód. 60, vol. XIX, f. 181. 
haver nenhuma ordem real que permitisse semelhante despesa. O impasse foi resolvido por Silva Pais, que ordenou que suas ordens fossem rigorosamente cumpridas $^{20}$. Apesar dos incentivos, o número de voluntários não deve ter sido grande, pois quando o governador ordenou a concentração dos efetivos do socorro no largo do Carmo, a fim de passar mostra às tropas de voluntários, também fez menção "a todos os mais que se têm sentado praça involuntários"

Numa emergência como esta, não era possível recorrer somente ao recrutamento dos indesejados pela sociedade, mas também foi preciso incorporar às expedições de socorro, que se sucederam de 1735 a 1737, elementos ativos na economia colonial. Além do comércio, a agricultura e a manufatura foram prejudicadas pelo recrutamento compulsório de uma importante parcela da sua mãode-obra. E, se a maioria dos militares enviados para Sacramento normalmente vinha do Rio de Janeiro e da metrópole, em situações de grande perigo mobilizavam-se todos os recursos humanos e materiais do Estado do Brasil.

A primeira expedição de socorro, sob o comando do sargento-mor Tomás Gomes da Silva, deixou o Rio de Janeiro em 15 de dezembro de 1735. Compunha-se de seis embarcações que levavam trezentos e sessenta marinheiros, duzentos e cinqüenta infantes, quarenta e dois Dragõe ${ }^{22}$ das tropas de Minas Gerais e trinta e cinco artilheiros. Ao lado dos militares seguiam ainda oitenta e seis prisioneiros e vinte e cinco índios (SÁ, 1993, p. 87), o que sugere que o sistema de recrutamento compulsório, aplicado à população masculina do Rio, foi insuficiente para completar o número de soldados necessários, tendo-se de recorrer aos prisioneiros.

A chegada dos reforços expedidos do Rio de Janeiro, em 6 de janeiro, foi muito festejada pela população de Colônia, principalmente pela guarnição, "cansada de levantar terra de dia e de dormir sobre as armas de noite"23. Porém, se a chegada dos reforços diminuía o ritmo de trabalho dos soldados através de uma melhor distribuição dos serviços, a sua presença implicava na criação de novos problemas, como o maior consumo de mantimentos e a

\footnotetext{
${ }^{20}$ Portaria do governador Silva Pais. Rio, 22/11/1735. Arquivo Nacional, cód. 60, vol. 19, ff. 187-188.

${ }^{21}$ Bando do governador Silva Pais. Rio, 08/12/1735. Arquivo Nacional,cód. 60, v. 19, f. 194v.

${ }^{22}$ Dragões eram os soldados de elite da cavalaria.

23 “Noticia Práctica del sitio de la Nueva Colonia del Sacramento...” Op. cit., p. 610.
} 
inexperiência militar de muitos dos soldados recém-chegados, o que deu origem a inúmeros atritos entre as forças de socorro e a população civil e militar de Sacramento.

Embora a chegada dos reforços não tenha alterado significantemente o equilíbrio de forças no Rio da Prata, serviu para diminuir a moral dos espanhóis, que viram que sem um bloqueio naval eficiente a praça poderia ser constantemente reabastecida de homens e provisões pelo Rio de Janeiro. Em 31 de janeiro, os espanhóis abandonaram o campo de bloqueio, retirando-se para o arraial de Veras, de onde diariamente mandavam uma companhia de cavalaria atacar os portugueses que se aventurassem a deixar o recinto fortificado. As forças espanholas ficaram então a cargo de um comandante, pois o governador Salcedo voltou a Buenos Aires, enquanto os índios voltavam para suas missões (Sylva 1993, pp. 93-95).

Enquanto se dava o recuo dos espanhóis, que desistiram momentaneamente de tentar a conquista da Colônia do Sacramento, contentando-se em isolá-la através da implantação de um campo de bloqueio que ia de costa a costa, continuava o esforço de guerra em Portugal e no Brasil. Na Bahia, o vice-rei, André de Melo e Castro, conde das Galveias (1735-1749), tratou de organizar uma expedição de socorro que saiu de Salvador, a bordo de dois navios, em 31 de dezembro de 1735. Compunha-se de um destacamento de duzentos soldados, retirados dos dois $\operatorname{Terços}^{24}$ que guarneciam a cidade, aos quais se acrescentaram três capitães de infantaria e um de artilharia, três alferes, seis sargentos e cinqüenta artilheiros. Os reforços foram divididos em quatro companhias: duas de sessenta soldados cada e uma de oitenta, enquanto outra reunia os cinquienta artilheiros. Além de um número considerável de militares, o socorro da Bahia trazia ainda provisões de alimentos e munição (Mirales 1900: 172).

Ao mesmo tempo em que se preparava uma nova expedição no Rio de Janeiro, chegaram à cidade os reforços enviados pelo vice-rei. Os soldados foram aquartelados em terra enquanto se aprontavam os navios para transportá-

\footnotetext{
${ }^{24}$ A expressão "Terço" origina-se na prática da divisão da infantaria romana em legiões e da alemã e francesa em regimentos de três mil homens. Como as frações da infantaria, na península ibérica, raramente excediam o número de mil homens, ou seja, a terça parte de uma legião ou um regimento, foram denominadas "Tercios" na Espanha e "Terços" em Portugal. Cf. Raphael BLUTEAU. Vocabulario Portuguez e Latino. Coimbra: Colégio da Companhia de Jesus, 1721.
} 
los ao Rio da Prata. A escala das tropas da Bahia no Rio trouxe o medo da deserção, muito comum numa época em que a disciplina militar era mantida através do uso constante da violência física. Para evitar a deserção em massa, Silva Pais, ordenou que todos os oficiais e soldados estivessem sempre a postos nos quartéis consignados, sendo castigados como desertores os que se ausentassem deles. O castigo incluía as pessoas que ajudassem os desertores, incorrendo em pena de cinco anos de degredo em Angola ${ }^{25}$. Porém não havia só o risco de deserções, pois enquanto se esperava pela partida da frota para Sacramento irromperam distúrbios entre os reforços vindos da Bahia e a guarnição do Rio de Janeiro, causando um número de baixas não especificado por Simão Pereira de Sá, entre mortos e encarcerados (Sá 1993: 94).

Em 11 de março de 1736, a frota, composta de três navios de alto bordo e quatro sumacas, deixou o porto do Rio, transportando duzentos infantes, cinqüenta artilheiros e cento e cinqüenta recrutas além de provisões para os sitiados. Porém a pequena frota não conseguiu chegar unida a seu destino, pois uma tempestade causou a separação dos barcos menores, um das quais se antecipou aos outros, chegando em Colônia com 22 dias de viagem com a notícia da vinda do socorro (Sá 1993: 95). A seis de abril chegaram a Sacramento três navios do Rio de Janeiro carregados de mantimentos e no dia 11 mais dois navios do Rio e da Bahia com soldados, mantimentos e munições ${ }^{26}$.

Em resposta ao pedido de ajuda de Antônio Gomes Freire de Andrade, que então acumulava os governos do Rio de Janeiro (1733-1763) e Minas Gerais (1735-1763), o conde de Sarzedas, governador de São Paulo (1732-1737), alegou que não tinha como acudir ao governador Vasconcelos, uma vez que a sua capitania não contava com tropas nem equipagem para organizar um socorro por terra numa distância tão grande como a que havia entre São Paulo e Colônia. Também julgava difícil reunir os paulistas sem lhes oferecer grandes vantagens, uma vez que a maioria deles encontrava-se dispersa pelas minas, sendo que os poucos que conseguira reunir haviam sido enviados ao Mato Grosso para atacar os índios paiaguás, que dificultavam o acesso a Cuiabá. Informava ainda que a guarnição de Santos não passava de duzentos e oitenta homens, carentes

\footnotetext{
${ }^{25}$ Bando de Silva Pais. Rio, 10/01/1736. Arquivo Nacional, cód. 60, vol. XIX, ff. 199-199v. 26 "Rellaçam do principio da Guerra da Collonia..." Op. cit., p. 48.
} 
das munições necessárias, e que também lhe era difícil contribuir com farinha para os socorros, porque havia falta dela em toda a capitania ${ }^{27}$.

À defecção de São Paulo seguiu-se a de Pernambuco, cujo governador não cumpriu a promessa que fez a Silva Pais no sentido de remeter ao Rio de Janeiro duzentos homens, que seriam incluídos nos socorros a serem enviados para Sacramento ${ }^{28}$. Duarte Sodré Pereira, governador de Pernambuco, foi severamente repreendido por Guedes Pereira, secretário de Estado, por agir com frouxidão na organização do socorro com que a capitania deveria contribuir para a manutenção de Colônia. Além da demora no apresto, a Coroa estranhou a ordem de suspensão dada pelo governador à organização da expedição de socorro, assim que recebeu a notícia de que os espanhóis levantaram o cerco depois da chegada dos reforços enviados pelo Rio de Janeiro. Deveria, pois, remeter com urgência para o Rio um destacamento dos melhores homens das guarnições pernambucanas e proceder ao recrutamento para substituir os que partiam para o sul. O governador ficava advertido que "em tudo o mais que se lhe pedir para ajuda da conservação ou restauração dos domínios daquelas partes ponha vossa senhoria a maior diligência e cuidado porque de toda negligência que houver neste particular se dará Sua Majestade por muito mal servido"29.

Também pressionado pela Coroa, Sarzedas somou-se ao esforço de guerra em 20 de maio de 1736, quando publicou um bando pelo qual prometia honrarias e concedia saque livre de gado, ouro, prata e o que mais fosse tomado ao inimigo aos homens que se alistassem no socorro a Colônia. A todos que se recusassem ao alistamento ou se escondessem dos recrutadores, ameaçava com os castigos destinados aos rebeldes e desertores. Às famílias que se dispusessem a ir povoar o Rio Grande do Sul, prometia a concessão de sesmarias, além dos privilégios e isenções que se davam aos povoadores ${ }^{30}$. Embora entre

${ }^{27}$ Carta de Sarzedas para Gomes Freire. Santos, 16/11/1735, in: Documentos Interessantes para a História e Costumes de São Paulo. São Paulo: Arquivo do Estado, 1902, vol. XLI, pp. 307-309.

${ }^{28}$ Carta de Silva Pais ao rei. Rio, 28/01/1736, in: Revista do Instituto Histórico e Geográfico do Rio Grande do Sul. Porto Alegre, I a IV trimestres de 1948, nº 109-112, p. 47.

${ }^{29}$ Carta de Guedes Pereira para Duarte Sodré Pereira. Lisboa, 27/07/1736, in: Revista do Instituto Histórico e Geográfico do Rio Grande do Sul. Porto Alegre, IV trimestre de 1946, no 104, p. 447.

${ }^{30}$ Bando do conde de Sarzedas. Santos, 20/05/1736, in: Documentos Interessantes para a História e Costumes de São Paulo. São Paulo: Arquivo do Estado, 1896, vol. XXII, pp. 105-106. 
os sitiados existisse a esperança de que dois mil paulistas viessem por terra para forçar os espanhóis a levantarem o cerco a Colônia ${ }^{31}$, o certo é que tudo não passava de boato ditado pelo desespero ou mesmo conscientemente criado para aumentar a moral da população. Os reforços de São Paulo na verdade não passavam de alguns homens chefiados por Cristóvão Pereira de Abreu, ${ }^{32}$ que tinha grandes interesses na exploração do gado selvagem (Sá 1993: 110).

A Coroa portuguesa também não deixou de incluir a metrópole no esforço de guerra. A notícia de que os espanhóis preparavam duas naus com reforços para D. Miguel de Salcedo levou D. João V a ordenar o apresto de alguns navios de guerra com destino a Colônia (Sá 1993: 107). A 25 de março de 1736, zarpavam de Lisboa duas naus de 60 peças e uma fragata de 54, sob o comando do coronel Luís de Abreu Prego que, com o pretexto de acompanhar a frota mercante do Rio de Janeiro, destinavam-se a reforçar a presença naval portuguesa no Rio da Prata. Seguia com o coronel Abreu Prego o mestre de campo André Ribeiro Coutinho, considerado um dos mais brilhantes oficiais portugueses, com larga experiência na Índia. Posteriormente, acrescentar-se-iam mais duas fragatas, que deveriam acompanhar a frota da Bahia, a qual zarpou em 21 de agosto. Os navios de guerra seguiam com uma tripulação maior do que a necessária, à qual se acrescentaria um destacamento a ser retirado da guarnição do Rio. Com relação à atuação que se esperava da frota, D. João $\mathrm{V}$ dava preferência à tomada de Montevidéu, mas também ordenava a fortificação da margem sul da barra do Rio Grande.

$\mathrm{Na}$ altura das ilhas Canárias, os navios de guerra comandados por Abreu Prego se adiantaram aos navios mercantes da frota e seguiram para o Rio de Janeiro, para onde a Coroa já havia mandado um navio com ordem para que o

\footnotetext{
31 "Sistema entre un Portuguez y un jenobes..." Archivo Regional de Colonia, Reg. 217, T5, doc. 4, f. 38 .

${ }^{32}$ Nascido, provavelmente, em 1680 em Ponte de Lima, Portugal Cristóvão Pereira de Abreu, deve ter vindo bem moço para o Brasil, onde uma das primeiras referências à sua pessoa é de 1702, quando, no Rio de Janeiro, arrematou o contrato dos dízimos dos couros extraídos nos campos da Colônia do Sacramento. Em 1710, Pereira de Abreu teria arrematado o contrato do tabaco do Rio de Janeiro e, no ano seguinte, participou das negociações que resgatou a cidade dos franceses comandados por Duguay-Trouin. Documentos datados de 1719 ainda fazem referência a Cristóvão Pereira de Abreu como residindo no Rio, onde se casou com D. Clara de Amorim, pertencente a uma das mais importantes famílias da cidade. Em 1722, estava em Colônia, onde se dedicou à extração e exportação de couros. Cf. PORTO, 1954, parte II, pp. 106-114.
} 
governador Gomes Freire de Andrade seguisse de Minas Gerais para o Rio de Janeiro, onde deveria assumir o governo da capitania. O brigadeiro José da Silva Pais, governador interino do Rio desde 12 de março de 1735, fora encarregado de armar alguns navios leves para se juntarem aos reforços que em breve chegariam de Lisboa, devendo se incorporar à expedição de socorro para comandar as operações terrestres contra os espanhóis (Barreto 1975: 9-17).

Apesar do novo ânimo que a notícia da vinda de reforços de Lisboa deu à população carioca, Silva Pais não deixou de encontrar dificuldades em recrutar marinheiros para equipar a frota. Por isso lançou um bando, pelo qual ordenava que todo o homem que houvesse sido marinheiro, ou o sendo e não servindo em outra embarcação, sentasse praça imediatamente sob pena de ter de trabalhar seis meses acorrentado nas obras de fortificação, aos quais se seguiriam dois anos de degredo em Angola. A mesma pena seria imposta às pessoas que os ocultassem ou não os denunciassem ${ }^{33}$.

Em 9 de junho de 1736, uma junta presidida por Gomes Freire, que, em maio, chegara de Minas Gerais (cujo governo interino deixara a Martinho de Mendonça Pina e Proença), decidiu que, aliviado o cerco a Sacramento, a frota de socorro deveria tentar conquistar Montevidéu e dar início a uma povoação no Rio Grande. A frota portuguesa deixou o Rio em 25 de junho e em 3 de julho chegou à ilha de Santa Catarina, aonde, no mês seguinte, chegou Cristóvão Pereira de Abreu com alguns homens de São Paulo. Investido com a patente de coronel de ordenanças, Abreu recebeu ordens de seguir até Laguna e recrutar mais gente para em seguida dirigir-se até a margem sul da barra do Rio Grande, onde deveria reunir gado vacum e cavalar para abastecer a tropa que futuramente se instalaria no local (César 1970: 106).

A esquadra deixou então a ilha de Santa Catarina com destino a Montevidéu, aonde chegou na noite de seis de setembro. Porém, ao observar as fortificações da cidade, os portugueses viram que não poderiam tomá-la de assalto como pretendiam. Deixando Abreu Prego no comando da frota, que bloqueava o porto de Montevidéu, Silva Pais e Ribeiro Coutinho se dirigiram a Colônia, onde se encarregaram do reparo das fortificações. Silva Pais ainda pretendeu atacar a frota espanhola, refugiada na enseada de Barregán, próxima a Buenos Aires, mas encontrou a oposição de Abreu Prego. A inação da esquadra portuguesa

\footnotetext{
${ }^{33}$ Bando do governador Silva Pais. Rio, 03/03/1736. Arquivo Nacional, cód. 60, vol. XIX, ff. $214 \mathrm{v}-215$.
} 
começava a preocupar o governador Vasconcelos, pois, em Colônia, escasseavam os mantimentos e difundiam-se as doenças (Barreto 1975: 19-24).

No inverno de 1736, aumentaram os protestos dos soldados, especialmente entre os cariocas e os baianos, que não estavam acostumados ao clima frio da região platina. Às doenças causadas pelo frio, contribuíam para aumentar o descontentamento dos soldados a falta de mantimentos e o atraso no pagamento dos soldos (Sylva 1993: 95). Mal desembarcado o destacamento da Bahia, surgiram os primeiros atritos entre os soldados e a população civil. Parece mesmo que os baianos trouxeram mais problemas que auxílio e, por fim, o governador Vasconcelos resolveu desembaraçar-se deles, mandando-os embarcar para Laguna a fim de buscar carne para o sustento da praça, de onde o destacamento saía "mal quisto com o povo por alguns insultos cometidos aos paisanos” (Sá 1993: 110).

O pequeno espaço físico abrangido pelas fortificações, que tornava difícil o cotidiano dos moradores, piorou com a chegada dos reforços, pois os alimentos não eram suficientes para todos. Quando terminaram os mantimentos trazidos pelos navios, os animais domésticos tiveram de ser abatidos para conter a fome da população. As poucas galinhas que restavam eram vendidas a quatro mil réis, os gatos custavam meio peso espanhol e um quarto de cão, oitenta réis. Ervas silvestres e ratos também serviram de fonte de alimentação para os sitiados, enquanto as poucas rações de carne salgada, muitas vezes já em estado de putrefação, eram reservadas aos doentes (Sá 1993: 105).

Mesmo quando chegavam novas remessas de alimentos através dos navios de socorro, não se sabia como cozinhá-las, pois não havia mais madeira disponível, e por isso "já não há casa que tenha porta interior, nem coisa de madeira que se não tenha queimado e muitos comprando carros para o mesmo efeito" ${ }^{34}$. Além do problema ocasionado pela falta de lenha, havia a circunstância de que a maior parte dos mantimentos recebidos era composta de farinha de mandioca e carne salgada, alimentos impróprios para serem consumidos pelos doentes, que ao invés de melhorarem, morriam por causa da dieta que lhes era imposta pelas circunstâncias ${ }^{35}$.

\footnotetext{
${ }^{34}$ Carta de Luís de Abreu Prego para Gomes Freire. Nau N. S. da Vitória, 04/01/1737, in: Revista do Instituto Histórico e Geográfico do RS. Porto Alegre, IV trimestre de 1946, nº 104, p. 349.

${ }^{35}$ Carta de Vasconcelos para Abreu Prego. Colônia, 11/02/1737, in: Revista do Instituto Histórico e Geográfico do RS. Porto Alegre, III trimestre de 1945, nº 99, p. 87.
} 
A fim de evitar o rápido consumo dos mantimentos, as autoridades acabaram por optar pela evacuação das pessoas que não estavam diretamente envolvidas com a defesa da praça, como mulheres e crianças. No navio que comandava o bloqueio a Montevidéu, o brigadeiro José da Silva Pais escreveu a Gomes Freire de Andrada em 24 de setembro de 1736, informando-lhe que mandara evacuar a população civil da Colônia de Sacramento, com o objetivo de poupar os mantimentos ${ }^{36}$. Alguns casais foram então enviados ao Rio de Janeiro, sendo que, em 1738, foram remetidos ao Rio Grande a fim de dar início ao povoamento da região ${ }^{37}$.

Enquanto a dificuldade em conseguir uma alimentação adequada causava um elevado número de doenças entre a guarnição e a população de Sacramento, a falta de alimentos frescos também era a principal responsável pelo aumento do número de doentes entre a tripulação da marinha de guerra. Muitas vezes todo o alimento disponível na frota resumia-se a farinha e água ${ }^{38}$, sendo que só se recorria à pesca quando faltava farinha ${ }^{39}$, situação responsável pela disseminação do escorbuto entre a tripulação e os soldados ${ }^{40}$. A nau Conceição chegou a ter duzentos doentes a bordo, a nau Vitória, noventa e cinco e a Lampadoza, cento e oitenta ${ }^{41}$. Em dezembro de 1736, Gomes Freire escrevia ao coronel Prego que, dos cento e dezessete doentes remetidos ao Rio de Janeiro, cinco morreram durante a viagem, mas muitos se restabeleceram antes da chegada, de modo que só quarenta e três foram internados no hospital ${ }^{42}$.

\footnotetext{
${ }^{36}$ Carta de Silva Pais para Gomes Freire. Nau N. S. da Vitória, 24/09/1736, in: Revista do Instituto Histórico e Geográfico do RS. Porto Alegre, IV trimestre de 1946, n 104, p. 388.

37 "Memória dos serviços prestados pelo mestre de campo André Ribeiro Coutinho, no governo do Rio Grande do Sul, dirigida a Gomes Freire de Andrada (1740)", in: Anais da Biblioteca Nacional. Rio de Janeiro, 1936, vol. L, p. 328.

38 "Relação da campanha do Rio da Prata, escrita por Henrique Manuel de Miranda Padilha, imediato da fragata Nossa Senhora da Esperança", in: Revista do Instituto Histórico e Geográfico do Rio Grande do Sul. Porto Alegre, III trimestre de 1945, nº 99, p. 73.

39 “Outra relação da guerra da Nova Colônia", in: Revista do Instituto Histórico e Geográfico do Rio Grande do Sul. Porto Alegre, III trimestre de 1945, nº 99, p. 116.

${ }^{40}$ Carta de Abreu Prego para Vasconcelos. Rio da Prata, 04/05/1737, in: Revista do Instituto Histórico e Geográfico do Rio Grande do Sul. Porto Alegre, III trimestre de 1945, no 99, p. 91. 41 "Outra relação da guerra da Nova Colônia", in: Revista do Instituto Histórico e Geográfico do Rio Grande do Sul. Porto Alegre, III trimestre de 1945, no 99, p. 116.

${ }^{42}$ Carta de Gomes Freire para Abreu Prego. Rio, 06/12/1736, in: Revista do Instituto Histórico e Geográfico do Rio Grande do Sul. Porto Alegre, IV trimestre de 1946, nº 104, p. 366.
} 
O impressionante número de homens que se restabeleceu durante a viagem do Rio da Prata para o Rio de Janeiro sugere que o fingimento de doenças era uma das formas de resistência ao recrutamento forçado. Gomes Freire irritava-se com as constantes enfermidades que acometiam as tropas, dizendo que, dos reforços da Bahia, logo voltaram oitenta e cinco, "sem mais remédio que dormirem algumas noites nos quartéis". Realmente, tudo indica que nem todos os que se queixavam de moléstias realmente estavam doentes, pois, quando Silva Pais pediu ao comandante da nau Conceição que enviasse ao hospital os 213 doentes que estavam a bordo, o número de enfermos subitamente se reduziu a vinte e seis, dos quais o brigadeiro achava que somente seis padeciam de alguma doença. Por isso Gomes Freire insistia que se fizesse um exame rígido entre os soldados que alegavam doenças para averiguar se realmente sofriam de algum mal, pois, para o governador do Rio, na maioria dos casos, as queixas dos soldados não passavam de "mandriices ou bisonharias"43.

Notícias sobre a saída de reforços espanhóis de Cádiz e a falta de resultados satisfatórios por parte da esquadra, motivaram a Coroa portuguesa a enviar uma nova força naval, composta de embarcações mais leves, próprias para a navegação platina, em 21 de agosto de 1736. A pequena frota, composta de quatro navios, chegou ao Rio de Janeiro em 30 de outubro e de lá saiu em primeiro de dezembro, com o reforço de novas levas de soldados do Rio, de Pernambuco e da Bahia. Com os reforços, que se reuniram à frota de Abreu Prego em 16 de dezembro, Silva Pais planejou atacar Montevidéu, porém mais uma vez o conselho de guerra, constituído pelos oficiais, mostrou-se contra o projeto. Deixando a maior parte da frota no bloqueio a Montevidéu, Silva Pais e Ribeiro Coutinho seguiram com as embarcações pequenas para Maldonado, onde a falta de água e madeira deitou por terra os planos de criar um estabelecimento. Restava como única alternativa a fortificação do Rio Grande de São Pedro (Barreto 1975: 24-28).

Nesse meio tempo, os homens de Cristóvão Pereira de Abreu já haviam construído no sítio de Rio Grande um reduto guarnecido com quatro peças de artilharia de pequeno calibre. Abreu também instituiu duas guardas, uma a duas léguas de distância do porto, às margens de um arroio, onde ficavam um tenente e dez soldados, e outra em São Miguel, a sessenta léguas de distância, guar-

\footnotetext{
${ }^{43}$ Gomes Freire para Abreu Prego. Rio, 25/02/1737, in: Documentos Interessantes para a História e Costumes de São Paulo. São Paulo: Arquivo do Estado, 1929, vol. L, pp. 296.
} 
necida por quarenta homens sob as ordens de um capitão (Sá 1993: 160). Apesar da energia com que Pereira de Abreu conduzia sua missão, não conseguiu evitar a deserção de alguns de seus homens, que retornaram para Laguna, onde se queixaram dele e do governador de São Paulo. De fato, a situação era bastante difícil, pois os homens não contavam com outro alimento que não fosse a carne do gado que caçavam, pois, apesar da piscosidade das águas da região, não tinham uma rede com que pudessem pescar ${ }^{44}$.

Silva Pais chegou ao Rio Grande em 19 de fevereiro de 1737, conduzindo cerca de 260 homens. Na praia, ordenou o início da construção de um forte que nomeou Jesus, Maria, José. A meia légua de distância, dirigiu a construção do forte de Santana, destinado a defender a futura povoação de um ataque por terra. Ainda instituiu as guardas do Chuí, do saco da Mangueira e do Taim, além de reforçar o sistema defensivo criado por Pereira de Abreu em São Miguel. Também deu ordens para a criação da estância real do Bojuru, estabelecida na margem norte da barra, com a finalidade de garantir o suprimento de gado e cavalos à guarnição (César 1970: 107-113).

Enquanto Silva Pais se encarregava da fundação do Rio Grande, a paz voltou ao Rio da Prata em primeiro de setembro de 1737, quando chegou a Sacramento a nau de guerra Boa Viagem com a notícia da assinatura do armistício, firmado em 16 de março do mesmo ano em Paris pelos representantes das Coroas portuguesa e espanhola. O armistício estabelecia que: soltarse-iam todos os prisioneiros e cessariam todas as hostilidades na América, onde tudo se manteria na mesma situação em que estivesse quando da chegada da notícia da paz, enquanto que as Coroas espanhola e portuguesa nomeariam embaixadores para a elaboração de um tratado definitivo. $\mathrm{O}$ item que garantia a manutenção do status quo permitiu aos espanhóis manter o bloqueio de Colônia, situação que levou Rego Monteiro a comentar que os portugueses ficaram "tão restritos que mais vitoriosos ficariam os espanhóis apesar de não terem tomado a praça" (Monteiro 1937, v. 1: 330).

O armistício chegara no momento oportuno, pois o imenso esforço de guerra já começa a preocupar as autoridades coloniais. Embora o vice-rei escrevesse à corte que não tinha os meios necessários para socorrer Colônia, uma vez que lhe faltavam munições, armas e mesmo dinheiro para pagar os Terços

\footnotetext{
${ }^{44}$ Carta de Cristóvão Pereira de Abreu para Gomes Freire. Rio Grande, 1737, in: Anais da Biblioteca Nacional. Rio de Janeiro, 1936, vol. L, pp. 326-327.
} 
da guarnição de Salvador, além de alegar que não encontrara no porto nenhum navio capaz que se pudesse armar para transportar os reforços a Sacramento ${ }^{45}$, conseguiu mandar novo socorro em 3 de dezembro de 1736. Composto de cem soldados retirados dos Terços da guarnição, cinqüenta artilheiros, dois capitães e um alferes, este segundo socorro chegou quando os espanhóis já haviam levantado o cerco, sendo, portando, enviado para reforçar o novo estabelecimento criado no Rio Grande de São Pedro (Mirales 1900: 172). O vice-rei, confidenciou ao governador de Minas Gerais que, para acudir Sacramento, seria "necessário destruir todas as praças da América dos meios de se poderem defender porque em todas vai faltando o dinheiro, a gente e os mantimentos" ${ }^{\text {"46 }}$.

De fato, o recrutamento forçado já começava a ameaçar a economia das áreas onde era praticado com maior intensidade. Em março de 1737, Martinho de Mendonça escrevia a Gomes Freire sobre a falta de oficiais nas forças de Minas Gerais, constantemente sangradas em benefício da Colônia do Sacramento. Dos últimos homens que enviara ao Rio de Janeiro, para dali seguirem rumo ao Prata, tecia um comentário pouco lisonjeiro, já que se tratavam de "novatos, e eram o último refugo de todos os destacamentos" ".77 Em maio, o mesmo queixava-se de que "nas vilas do caminho velho se prende para a Colônia não só os vadios e moradores, mas os homens do caminho que vão buscar carregações ou vêm com elas" ${ }^{48}$. Preocupava-o, então, o fato de que o abuso no recrutamento compulsório, praticado nos caminhos que ligavam ao litoral, poderia gerar uma crise no abastecimento de Minas Gerais.

O recrutamento compulsório também servia como uma maneira eficaz de desembaraçar-se de alguma pessoa inconveniente. Por provisão real de 30 de janeiro de 1738, José Inácio da Fonseca conseguiu licença de um ano a fim de voltar a Portugal para resolver negócios pendentes. Queixava-se de que devido a desavenças com seu sócio, este o inscrevera como soldado, o que lhe arruinou o comércio e o crédito, pois

${ }^{45}$ Consulta do Conselho Ultramarino. Lisboa, 15/06/1736, in: Documentos Históricos. Rio de Janeiro: Biblioteca Nacional, 1951, vol. XCI, pp. 58-61.

${ }^{46}$ Carta do conde das Galveias para Martinho de Mendonça. Salvador, 10/01/1737, in: Revista do Arquivo Público Mineiro. Belo Horizonte, 1911, vol. II, p. 217.

${ }^{47}$ Carta de Martinho de Mendonça para Gomes Freire. Vila Rica, 26/03/1737, in: Revista do Arquivo Público Mineiro. Belo Horizonte, 1911, vol. II, p. 402.

${ }^{48}$ Carta de Martinho de Mendonça para Gomes Freire. Vila Rica, 22/05/1737, in: Revista do Arquivo Público Mineiro. Belo Horizonte, 1911, vol. II, p. 429. 
vários comerciantes de Lisboa lhe fiaram grande quantidade de fazendas, sendo que só a D. Paulo Jerônimo Médici devia mais de dez mil cruzados ${ }^{49}$. Em 1742, Manuel Tavares da Silva, soldado Dragão da guarnição de Rio Grande, representou ao brigadeiro Silva Pais "que ele suplicante veio potenciosamente das Minas, por pessoa sua inimiga, que avilosamente lhe maquinou a destruí-lo"

De fato, não era raro que algumas pessoas abusassem do poder que lhe fora conferido pelo sistema de ordenanças, a fim de proceder a vinganças pessoais. Martinho de Mendonça escrevia a Gomes Freire, em 1736, que "os oficiais das milícias nada desejam tanto como estas prisões" ${ }^{\text {.51 }}$. Nos momentos de emergência, como durante o cerco espanhol a Colônia, as autoridades perdiam os poucos escrúpulos que ainda tinham com relação ao recrutamento compulsório e fechavam os olhos às arbitrariedades executadas pelos recrutadores. Não é à toa que personalidades que se destacavam nas comunidades fizessem questão de obter cargos de comando nas ordenanças. Romero Magalhães sintetizou o poder de que estavam investidos com uma frase: "Fazer soldados, poder tremendo! Não os fazer, maior ainda" (Magalhães apud Costa 1995: 121).

Por sua vez, as constantes remessas de alimentos com que as cidades do litoral brasileiro eram obrigadas a contribuir para com o esforço de guerra prejudicavam bastante a população local. D. Pedro Antônio d'Estrés, imediato da nau Nossa Senhora da Conceição, avisara o governador Gomes Freire que seria impossível manter por muito tempo a Colônia do Sacramento sem garantir o acesso livre à campanha, onde se poderiam conseguir alimentos frescos, pois os salgados continuaram a causar muitas doenças e o Rio de Janeiro não poderia continuar a remeter mantimentos sem experimentar escassez de víveres que já acometia Salvador ${ }^{52}$.

Apesar do imenso esforço de guerra, que possibilitou o envio para a Colônia do Sacramento de navios, homens e mantimentos, os resultados não foram os esperados. A superioridade naval dos portugueses no Rio da Prata não pos-

\footnotetext{
${ }^{49}$ Provisão real e despacho de licença do cabo José Inácio da Fonseca. Rio Grande, 10/12/1742, in: Anais do Arquivo Histórico do Rio Grande do Sul. Porto Alegre, 1977, vol. 1, pp. 190-191.

${ }^{50}$ Requerimento que fez Manuel Tavares. Rio Grande, 18/07/1742, in: Anais do Arquivo Histórico do Rio Grande do Sul. Porto Alegre, 1977, vol. 1, p. 178.

${ }^{51}$ Carta de Martinho de Mendonça para Gomes Freire. Vila Rica, 28/10/1736, in: Revista do Arquivo Público Mineiro. Belo Horizonte, 1911, vol. II, p. 374.

${ }^{52}$ Carta de Pedro Antônio d'Estrés para Gomes Freire. Nau N. S. da Conceição, 19/12/ 1736, in: Revista do Instituto Histórico e Geográfico do Rio Grande do Sul. Porto Alegre, I a IV trimestres de 1948, n 109-112, p. 18.
} 
sibilitou a tomada de Montevidéu, como era o desejo de D. João V, e os reforços não foram suficientes para obrigar os espanhóis a levantar o cerco a Colônia, embora conseguissem impedir a tomada da fortaleza pelo inimigo. A atuação da frota foi prejudicada pela falta de um comando centralizado, pois a carta régia em que constavam as ordens a Abreu Prego não estabelecia precedências entre o comandante da frota, Prego, o comandante da expedição de socorro, Silva Pais, e o governador de Sacramento, Vasconcelos. O comando superior ficara a cargo do governador do Rio de Janeiro, Gomes Freire de Andrada, que se conservava longe do teatro de operações (Barreto 1975: 15).

Embora o armistício de 1737 não tenha significado uma vitória para os portugueses, além da garantia da manutenção de Colônia, o mesmo salvou o Estado do Brasil de um eminente colapso de seu sistema defensivo, já que as principais capitanias estavam exauridas de homens e mantimentos e a continuação do recrutamento compulsório poderia comprometer gravemente a economia colonial. Porém, até a assinatura de um novo tratado que delimitasse precisamente a fronteira meridional, a situação continuaria tensa no Rio da Prata. Por sua vez, a fortificação erigida no Rio Grande de São Pedro continuava a exigir mais homens, armamentos e mantimentos para sua manutenção. Como as capitanias do Rio de Janeiro, Minas Gerais e Bahia foram as que mais contribuíram para o esforço de guerra, se encontravam então esgotadas de recursos para continuar enviando reforços para o sul.

A morte do conde de Sarzedas, em 1737, quando viajava para Goiás a fim de organizar o combate contra os índios paiaguás, colocou a capitania de São Paulo sob o governo interino de Gomes Freire de Andrada ${ }^{53}$. Aproveitando-se dessa situação, Gomes Freire não perdeu tempo em inserir os paulistas no esforço de guerra. Em abril de 1738, escreveu ao governador de Santos, ordenando-lhe que conseguisse o maior número de recrutas possíveis para enviar ao Rio Grande ${ }^{54}$. A partir desse momento, a capitania de São Paulo passou a ser a principal responsável em sustentar com homens e alimentos a defesa da fronteira meridional ${ }^{55}$, já que, além das capitanias brasileiras envolvidas no esforço de guerra, a metrópole

\footnotetext{
${ }^{53}$ Gomes Freire governou a capitania de São Paulo por duas vezes: 1737-1739 e 17481763, in: (Silva 1994: 50).

${ }^{54}$ Carta de Gomes Freire para o governador de Santos. Vila Rica, 24/04/1738, in: Revista do Arquivo Municipal. São Paulo, 1941, vol. LXXX, pp. 166-167.

${ }^{55}$ Sobre o importante papel de São Paulo, a partir da segunda metade do século XVIII, nas guerras do sul, consultar: PEREGALLI, 1986.
} 
também encontrava dificuldades em garantir a segurança do novo povoado de Rio Grande, pois teve que concentrar suas forças para defender a Índia portuguesa. Entre 1737 a 1740, os maratas conquistaram Baçaim e a fértil província do norte. A situação crítica no Oriente obrigou a Coroa a continuar o esforço de guerra na forma de constantes envios de homens, armamentos e dinheiro para a Índia, tornando impossível socorrer Sacramento e Rio Grande caso estourasse um novo conflito com os espanhóis (Boxer 1969: 305).

\section{Referências Bibliográficas}

ALMEIDA, Luís Ferrand de. A Colônia do Sacramento na Época da Sucessão de Espanha. Coimbra: Faculdade de Letras da Universidade de Coimbra, 1973.

ALVES, Odair Rodrigues. Homens que Governaram São Paulo. São Paulo: Nobel/EDUSP, 1986.

AZAROLA GIL, Luis Enrique. La Epopeya de Manuel Lobo. Madrid: Compañía Ibero-Americana de Publicaciones, 1931.

BARRETO, Abeillard. "A Expedição de Silva Pais e o Rio Grande de São Pedro". In: História Naval Brasileira. Rio de Janeiro: Ministério da Marinha, Serviço de Documentação Geral da Marinha, 1975, vol. 2, tomo 2, pp. 9-54.

BICALHO, Maria Fernanda Baptista. A Cidade e o Império: O Rio de Janeiro na Dinâmica Colonial Portuguesa - Séculos XVII e XVIII. Tese de Doutorado apresentada ao Depto. de História da FFLCH da Universidade de São Paulo, 1997.

BOXER, Charles. A Idade de Ouro do Brasil (Dores do Crescimento de Uma Sociedade Colonial). 2a ed. São Paulo: Companhia Editora Nacional, 1969.

CESAR, Guilhermino. História do Rio Grande do Sul - Período Colonial. Porto Alegre: Globo, 1970.

COARACY, Vivaldo. O Rio de Janeiro no Século 17. Rio de Janeiro: José Olympio, 1944.

CORTESÃO, Jaime. Alexandre de Gusmão e o Tratado de Madrid. Rio de Janeiro: Instituto Rio Branco, 1950, parte I, tomo I (1695-1735). . (introdução, notas e sumários). Manuscritos da Coleção de Angelis: Tratado de Madrid. Antecedentes: Colônia do Sacramento (1669-1749). Rio de Janeiro: Biblioteca Nacional, 1954.

COSTA, Fernando Dores. "Os Problemas do Recrutamento Militar no final do Século XVIII e as Questões da Construção do Estado e da Nação”. Análise 
Social: Revista do Instituto de Ciências Sociais da Universidade de Lisboa. Lisboa: quarta série, $\mathrm{n}^{\circ} 130$, vol. XXX, 1995 - 1º pp. 121-155.

. "Condicionantes Sociais das Práticas de Recrutamento Militar (16401820)". Separata das Actas do VII Colóquio "O Recrutamento Militar em Portugal”. Lisboa: Ramos, Afonso \& Moita, Lda, 1996.

. "O Bom Uso das Paixões: Caminhos Militares na Mudança do Modo de Governar". Análise Social: Revista do Instituto de Ciências Sociais da Universidade de Lisboa. Lisboa: quarta série, $\mathrm{n}^{\circ}$ 149, vol. XXXIII, 1998 - 5º pp. 969-1.017.

LISANTI, Luís (Org.). Negócios Coloniais (Uma Correspondência Comercial do Século XVIII). Brasília: Ministério da Fazenda; São Paulo: Visão Editorial, 1973. MIRALES, José de. "História Militar do Brasil" [1762]. Anais da Biblioteca Nacional. Rio de Janeiro, 1900, vol. XXII.

MONTEIRO, Jonathas da Costa Rego. A Colônia do Sacramento (1680-1777). Porto Alegre: Globo, 1937, vol. 1.

PEREGALLI, Enrique. Recrutamento Militar no Brasil Colonial. Campinas: Unicamp, 1986.

PORTO, Aurélio. História das Missões Orientais do Uruguai. $2^{\text {a }}$ ed. Porto Alegre: Selbach, 1954, 2v.

PRADO JÚNIOR, Caio. Formação do Brasil Contemporâneo. $5^{\mathrm{a}}$ ed. São Paulo: Brasiliense, 1957.

RUSSEL-WOOD, A. J. R. “A Emigração: Fluxos e Destinos”, in: BETHENCOURT, Francisco e CHAUDHURI, Kirti (dir.). História da Expansão Portuguesa. Lisboa: Círculo de Leitores, 1998, vol. 3, pp. 158-168.

SÁ, Simão Pereira de. História Topográfica e Bélica da Nova Colônia do Sacramento do Rio da Prata [1737]. Porto Alegre: Arcano 17, 1993.

SILVA, Maria beatriz Nizza da (coordenação). Dicionário da História da colonização Portuguesa no Brasil. Lisboa: Verbo, 1994.

SOUZA, Laura de Mello e. Desclassificados do Ouro: A Pobreza Mineira no Século XVIII. $3^{\text {a }}$ ed. Rio de Janeiro: Graal, 1990.

SYLVA, Silvestre Ferreira da. Relação do Sítio da Nova Colônia do Sacramento. Facsímile da edição de 1748. Porto Alegre: Arcano 17, 1993. 


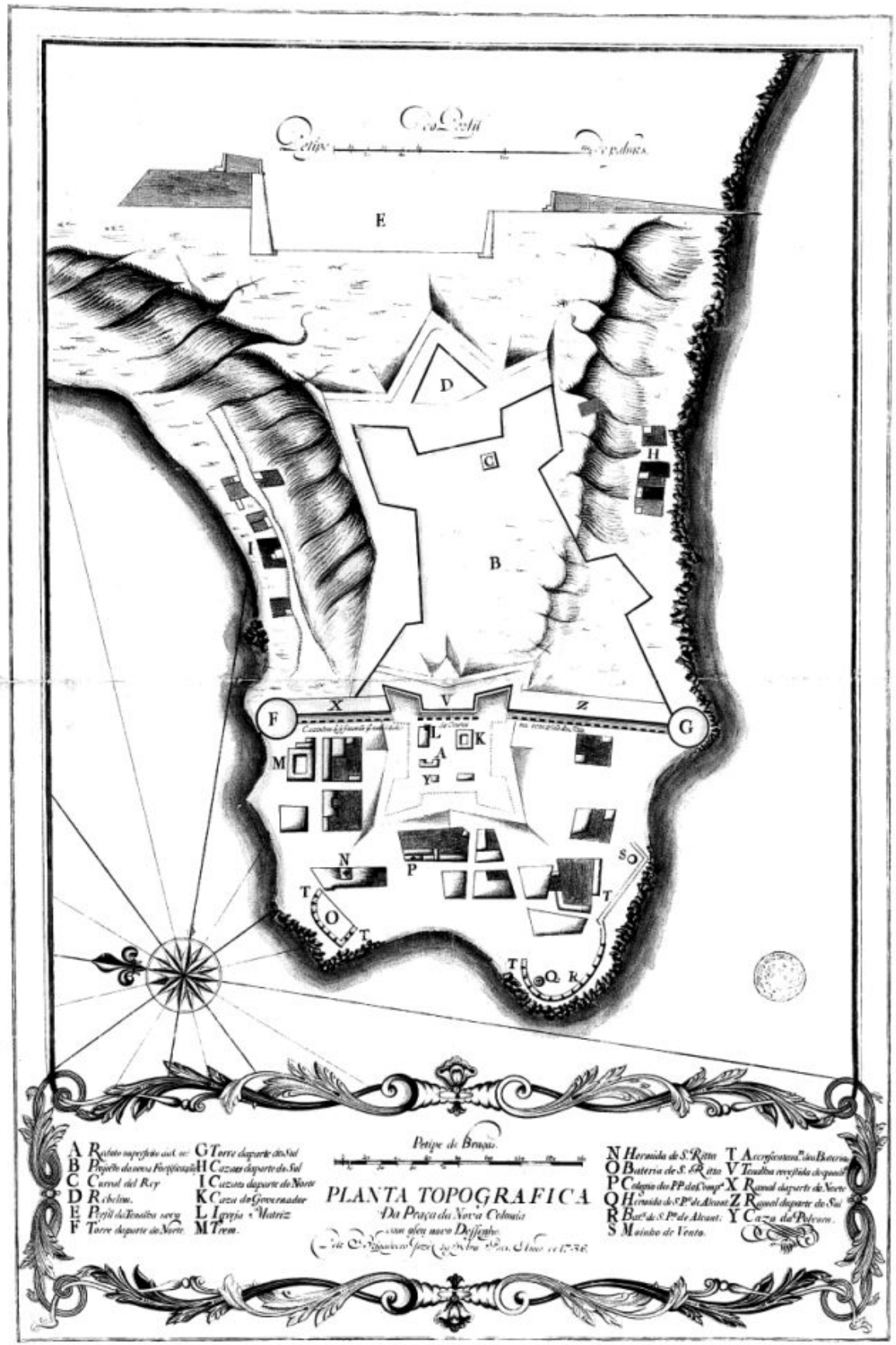

